\title{
ANTEMORTEM, PERIMORTEM AND POSTMORTEM BONE FRACTURE: COULD HISTOPATHOLOGY DIFFERENTIATE BETWEEN?
}

\author{
Melad Gad Paulis and Dalia Mohamed Ali* \\ *Forensic Medicine and Toxicology Department, Faculty of Medicine-Minia University, Egypt
}

\begin{abstract}
One of the important duties of the forensic experts is to differentiate between antemortem, perimortem, and postmortem bone fracture to estimate the postmortem interval. This study aimed to differentiate between antemortem, perimortem and postmortem bone fracture in late postmortem interval by histopathological technique. Sixty rats were equally divided into 6 groups. The first, second, third, and fourth groups involved rats that their left femora were fractured and left alive for 6, 3,1 days and $12 \mathrm{hr}$. before scarification respectively. The fifth and sixth groups included rats that their left femora were fractured just before death and 2 hours postmortem respectively. Bone fracture was examined 3 and 6 days postmortem. Bone samples were stained with hematoxylin and eosin stain $(\mathrm{H} \& \mathrm{E})$, trichrome stain, and Prussian blue (iron stain). Hemorrhage, the number of osteocyte nuclei, the number of bone marrow nuclei, and the degree of bone marrow dehydration were assessed. Our results revealed that hemorrhage was more evidenced in 1-day fracture, then 3 days and 12 hours, while, less in 6 days and at time of death. It was absent in postmortem fracture. There were significant decreases in the number of osteocytes and bone marrow nuclei, bone marrow hydration, and Prussian blue when examined at 6 days postmortem in comparing with 3 days postmortem. This study concluded that H\&E and trichrome stain succeeded in estimation of the age of the long bone fracture and differentiation between antemortem, perimortem and postmortem fracture, while Prussian blue stain showed insignificant changes in fracture produced just before death.
\end{abstract}

Keywords: wound age, bone fracture, antemortem, postmortem, hemorrhage. 


\section{INTRODUCTION}

It is a vital task for forensic experts to determine the vitality (whether antemortem or postmortem) and age of tissues injury. This mission is crucial in determining the manner and cause of death (Ishida et al., 2018). Histological, immunohistochemical and different chemical methods were employed to achieve this task (Dettmeyer, 2018, Nosaka et al., 2017, El-Noor et al., 2017). The skin had the lion's share of this work in comparing to other tissues as muscles (Sun et al., 2017a), and bone (Boer et al., 2015). In addition, most of the research examined wound vitality at death or shortly postmortem (within $24 \mathrm{~h}$ postmortem) (Sun et al., 2017b). There is a lack regarding the effect of postmortem decomposition on this healing process, and whether it could be estimated in late postmortem interval or not.

A mainly critical subject in this sense is the study of bone trauma and determining the time of bone fracture regarding the time of death. Anthropologists classified the timing of trauma to antemortem, perimortem, and postmortem. Antemortem trauma that occurs before death and characterized by signs of healing at the site of trauma (Wedel and Galloway, 2013). The perimortem that occurs at death. Postmortem fractures that occur after death and are mostly associated with autolytic processes (George et al., 2016).

Antemortem trauma has a big value for forensic pathologists as it is easily identified due to signs of healing (Galloway et al., 2014). On the other hand, both perimortem and postmortem trauma is difficult to be differentiated (Christensen et al., 2014). Moreover, there are many environmental factors can alter the characters of bone injuries, such as temperature, soil, moisture, fire and plants (Karr and Outram, 2015, Karr and Outram, 2012).

It has been reported that the morphology, color changes and texture of edges of the bone fracture can distinguish between the perimortem and postmortem fracture, while, this is still query for forensic experts, particularly 
with fresh bones. (Scheirs et al., 2017)

have revealed that the macroscopic pattern of bone fractures is only helpful in the diagnosis of perimortem and antemortem fracture only after 10 to 14 days. Cattaneo et al., (2010) have reported that forensic traditional methods cannot resolve this problem; while, forensic histopathology may be helpful to reveal some vital reactions in bone fracture. The histopathology techniques could develop the forensic diagnostic efficiency.

This study aimed to distinguish between the antemortem, perimortem and postmortem bone fracture in rat femora in late postmortem interval and determine the effect of duration of the postmortem on the bone fracture by histopathological techniques.

\section{MATERIALS AND METHODS}

All experimental design and procedures were ap proved by the ethical committee of Faculty of Medicine, Minia University. Adult male waster rats weighting 180-200 g were purchased from the faculty of Veterinary, Minia
University. Rats were left for one week in the same experimental conditions before starting the study for acclimation. Animals were kept in standard living conditions (temperature $(25 \pm 3 \mathrm{C})$, and 12-h light/dark cycles). Rats were allowed free access to tap water and standard rodent chow.

Fracture of the left rat femur was induced by a plier according to (Handool et al., 2018). The fracture was done under general anesthesia using ketamine $(70 \mathrm{mg} / \mathrm{kg})$ and xylazine $(5 \mathrm{mk} / \mathrm{kg}) \quad$ intraperitoneal. The compressing surface was applied the mid-shaft of the left femur. Pressure was applied gradually until the cracking sound of bone fracture was heard. A small bandage was applied to the fractured limb to facilitate the free mobility of the rats. Ketoprofen (Ketofan® ${ }^{\circledR}$, Amriya Pharma, Egypt) was given as an analgesic for groups that left for 6,3 , and 1 days and $12 \mathrm{~h}$ before scarification $\quad(5 \mathrm{mg} / \mathrm{kg} \quad$ subcutaneous /day).

Sixty rats were equally divided into 6 groups. The first, second, and third 
groups involved rats that their left femora were fractured and left alive for 6,3 , and 1 days before scarification. The fourth group involved rats that their left femora were fractured and left for 12 hours before scarification. The fifth group involved rats that their left femora were fractured just before death. The sixth group included rats that their left femora were fractured 2 hours after death. This group was considered, as a control group as there was no hemorrhage or tissue reaction postmortem. All rats were sacrificed by decapitation. Rats were buried in soil to a depth of $20 \mathrm{~cm}$. The soil type at this site is sandy loam with an average $\mathrm{pH}$ of 5.5. The experiments occurred during spring (March). Three days after death, 5 rats from each group were excavated. Six days after death, the remaining 5 rats were exhumed. After excavation, the left leg was removed and washed thoroughly with tap water. Femora were carefully dissected and placed in sealed plastic containers and stored at $-20^{\circ} \mathrm{C}$ to prevent further degradation until the time of histological staining.
Bone was fixed in $10 \%$ neutral buffered formalin for $48 \mathrm{~h}$, and then decalcified in $10 \%$ ethylene diamine tetra-acetic acid (EDTA). Tissue processing, including dehydration, clearing, impregnation, and embedding, was done through graded ethanol, xylol, and paraffin.

Histologic sections with a thickness of $6 \mu \mathrm{m}$ were prepared and then the samples were routinely stained with hematoxylin and eosin staining method $(\mathrm{H} \& \mathrm{E})$ is a standard staining procedure widely used in the field of pathology. Nine sections were prepared from each sample (3 for each used stain). Samples were stained with a blue basophilic stain, which stains nuclei and counter stained with a red eosinophilic stain that stains the extracellular matrix and other tissue structures. Trichrome stain is a staining method comprised of three stains that differentially stain types of connective tissue. Collagen and connective tissues are stained blue, nuclei are stained dark blue or purple, and muscle and red blood cells are stained red. Prussian blue is an 
iron stain indicate hemorrhage (Suvarna et al., 2018).

Sections were observed by Olympus light microscope (Japan). Images were captured using a digital camera mounted on the microscope and connected to a computer. Different histological parameters were evaluated using free image analysis software ImageJ.

For comparative analysis of histological changes in different groups, variable scoring systems were used for each histopathological parameter. This scoring system was used according to Powel (Powell, 2015) with some modifications. In $H \& E$ and trichrome stains, 4 parameters were assessed namely hemorrhage, the number of osteocyte nuclei, the number of bone marrow nuclei, and the degree of bone marrow dehydration. Hemorrhage was noticed around the fracture site. If there was no noticeable hemorrhage, it was given a score "1". If there were mild, moderate, or marked hemorrhage, it was given a score "2", “3”, or " 4 " respectively. The number of osteocyte nuclei was expressed as a percentage using the following formula:

Percentage of osteocyte nuclei $=$ the number of lacunue with osteocyte nuclei the total number of lacunae

According to the obtained percentage of osteocyte nuclei, four scales were classified. A score "1", "2", " 3 ", or "4" if approximately $0-25 \%, 26$ $50 \%, 51-75 \%$, or $76-100 \%$ of osteocyte nuclei were visible respectively.

Bone marrow nuclei were calculated using the following formula:

\section{Percentage of bone marrow nuclei $=$} the area occupied by bone marrow nuclei the total bone marrow area $\mathrm{x} 100$

According to the obtained percentage of marrow nuclei, four categories were classified. A score "1" if approximately $0-25 \%$ of marrow nuclei were visible. A score " 2 ", “3", or " 4 " if approximately $26-50 \%, 51-75 \%$, or $76-$ $100 \%$ of marrow nuclei were visible respectively.

Bone marrow dehydration this was determined by the density of marrow and the area covered by the extracellular matrix. It was given a score "1", "2", or 
" 3 " if there were no, moderate, or pronounced dehydration respectively.

Categorical classification of Prussian blue staining was expressed as " 1 " if no Prussian blue was noticed and "2", "3", or " 4 " if it was present in the examined field in mild, moderate, pronounced amount respectively.

Three non-overlapping visual filed were examined from each slide. The average score for each animal was obtained for each parameter in the examined fields in the 3 slides.

Statistical analysis:

Data were expressed as mean $\pm \mathrm{SD}$. As data did not show normal distribution, non-parametric tests, MannWhitney U test with Bonferroni correction. All $\mathrm{P}$ values $<0.05$ were considered statistically significant. All statistical procedures were conducted using SPSS 22 software on a personal computer.

\section{RESULTS}

Histopathological examination of group 1 that exhumed 3 days after rat scarification showed well-evidenced fracture healing in the form of a provisional fibrous callus. In addition, blood vessels in the bone marrow spaces and musculature showed severe damage (fig1-a). Bone tissue section revealed well-preserved numbers of both osteocytes and marrow nuclei. There was slight marrow dehydration (fig.1-b). Hemosiderosis was seen in-between bone fragment and accompanied by few hemorrhagic red blood cells score (fig.1c).

On the other hand, group 1 that dissected 6 days after burial, a reduction of bone fragments resorption was seen. Sloughing of periosteal outer fibrous layer and autolysis of inner osteogenic layers that represented empty lacunar spaces (fig.2-a). Bone tissue section revealed decreased numbers of both osteocytes and marrow nuclei (fig.2-b). There was a moderate amount of marrow dehydration. Hemosiderosis was seen inbetween bone fragment and the small hemorrhagic area was seen (fig.2-c).

Histopathological examination of group 2 showed that the bone tissue section at the point of fracture has 
fibroblasts proliferation and angiogenesis and development of granulation tissue within the 3 days of dissection (fig.3-a). Bone tissue section revealed there are still numerous both osteocytes and marrow nuclei (but less than that of group 1). There was minimal marrow dehydration (fig.3-b). Hemosiderosis was absent in-between bone fragment and several congested capillaries and hemorrhage (fig.3-c).

The same group that dissected 6 days after burial, revealed autolytic alterations of the bone adjacent to the fracture line. It is evident by empty some lacunar spaces due to death of osteocytes. A numerous number of bone fragments scatted in the surrounding autolysis fascia were noticed. The disappearance of granulation tissues and roughness of fracture bone surfaces were shown (fig.4-a). Bone tissue section revealed a decreased number of both osteocytes and marrow nuclei. Presence of marrow dehydration represented as empty bone marrow spaces from cells (fig.4-b). Few hemosiderin depositions between bone fragment minimal hemorrhages (fig.4-c).
Examination of bone fractures 1 day before rat scarification showed acute hemorrhage at the point of fracture secondary to vascular injury with the accumulation of a fusiform hematoma. In addition, deposited fibrin in the hematoma with edema was observed at 3 days of dissection (fig.5-a). Bone tissue section revealed numerous osteocytes and marrow nuclei. There was minimal amount of marrow dehydration (fig.5-b). Hemosiderosis was clearly demonstrated in-between bone fragment with a massive area of hemorrhage (fig.5-c). After 6 days of dissection of rats from group 3, autolytic changes of bone marrow and empty of some lacunar spaces of osteolytic cells were seen (fig.6-a). Bone tissue section revealed decreased both osteocytes and marrow nuclei. Increased marrow dehydration represented as empty bone marrow spaces from cells (fig.6-b). Hemosiderosis was minimally found inbetween bone fragment and little amount of hemorrhage (fig.6-c).

Tissue section of bone fracture area at $12 \mathrm{~h}$ before rats' death (group 4) and 
dissected 3 days after burial revealed a marked separation of two fracture bone ends by bone marrow cells and fragmented bony trabeculae (fig.7-a). Bone tissue section revealed score numerous visible osteocytes and marrow nuclei. Slight marrow dehydration was noticed (fig.7-b). There was a moderate amount of hemosiderin particles inbetween bone fragment with varied sizes hemorrhagic areas (fig.8-c). On other side, after 6 days of dissection of the same group, complete damage of bony tissue at the site of fracture which characterized by fragmentation of bony tissue with empty of some lacunar spaces of osteolytic cells (fig.8-a). Bone tissue section revealed score decreased a number of both osteocytes and marrow nuclei. Presence of marrow dehydration represented as empty bone marrow spaces from cells (fig.8-b). There was a minimal amount of hemosiderin pigment and hemorrhage in-between bone fragment (fig8-c).

In group 5 (fracture induced just before rats' death) that examined 3 days after death, fracture bony tissue showed complete separation of two ends of fractured bone by a homogeneous eosinophilic material mainly clotted blood cells (fig.9-a). Autolyzed bone marrow cells and a numerous number of bone fragments were seen. Bone tissue section numerous both osteocytes and marrow nuclei. There was a minimal amount of marrow dehydration (fig.9-b). Hemosiderosis was minimally inbetween bone fragment score, on other side, a hemorrhagic area in form of free red blood cells was also noticed (fig.9-c). Six days after exhumation of rats of the same group, the fractured bone ends showed autolytic changes characterized by complete damage of endosteum, which appeared as the rough irregular surface. The osteocytes represented as deep eosinophilic nuclei without clear lacunar spaces after (fig.10-a). Bone tissue section revealed a decreased number of both osteocytes and marrow nuclei. Presence of marrow dehydration represented as empty bone marrow spaces from cells (fig.10-b). Hemosiderosis was clearly demonstrated 
in-between bone fragment and free red blood cells was seen (fig.10-c).

The histological findings of bone fracture induced $2 \mathrm{~h}$ postmortem showed autolytic changes of osteocytes and empty of some lacunae, which scattered in bone tissue section at 3 days of dissection (fig.11-a). Bone tissue section revealed numerous both osteocytes and marrow nuclei. Slight marrow dehydration was noticed (fig.11-b). Absent of hemosiderin particles inbetween bone fragment was recorded and no hemorrhagic spots were seen (fig.11-c). In addition, 6 days after dissection, complete damage of bone tissue and disappearance of both some osteocytes and their lacunae were seen (fig.12-a). Bone tissue section revealed decreased both osteocytes and marrow nuclei. Marked marrow dehydration was seen (fig.12-b). No hemosiderin particles or hemorrhage was detected (fig.12-c).

As regard as the results of the scoring system of different examined histopathological parameters, the number of visible osteocyte nuclei decreased significantly in case of bone fracture 3 and 1 day before scarification. In contrast, in 6 days, $12 \mathrm{~h}$ and just before death, it showed insignificant changes when compared with their number in case of postmortem fracture. These changes were evident in both $\mathrm{H} \& \mathrm{E}$ (table 1) and trichrome (table 2) stained slides.in addition, these findings were true in the examination of bone 3 and 6 days postmortem.

Bone marrow nuclei examined by $\mathrm{H} \& \mathrm{E}$ and trichrome stains were significantly different all groups when compared with postmortem fracture. This was true in bone examined 3 days postmortem but not in case of examination of bone 6 days after exhumation. These findings were evident in $\mathrm{H} \& \mathrm{E}$ and trichrome stained slides (table $1 \& 2$ ).

The degree of bone marrow dehydration showed insignificant changes in examined bone fracture when produced antemortem and that produced postmortem. These were the same results in both $\mathrm{H} \& \mathrm{E}$ and trichrome stained slides (table $1 \& 2$ ). 
There were pronounced hemorrhage in fracture produced 3,1 days, and $12 \mathrm{~h}$ antemortem (group 2, 3, and 4). There was mild hemorrhage in 6 days antemortem and just before death fractures. All groups give significant changes in comparing with the hemorrhage score produced postmortem. These changes were true for both $\mathrm{H} \& \mathrm{E}$ and trichrome stained slides. In addition, hemorrhage was more evident in bone examined 3 days postmortem than that examined 6 days postmortem (table $1 \&$ 2). Prussian blue gave similar findings except that that for fracture induced just before death; it was insignificant from postmortem fracture (table 1).

All histopathological parameters showed significant changes in comparing between 3 and 6 days postmortem discussion (table $1 \& 2$ ). 
Table 1: Quantitative assessment of different histopathological parameters in slides stained with $H \& E$ and Prussian blue stains.

\begin{tabular}{|c|c|c|c|c|c|c|c|c|c|c|c|}
\hline \multirow{5}{*}{ 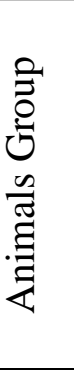 } & \multirow{5}{*}{$\begin{array}{l}\text { Time of } \\
\text { bone } \\
\text { fracture }\end{array}$} & \multicolumn{10}{|c|}{ Stain Affinity Score } \\
\hline & & \multicolumn{8}{|c|}{$\mathrm{H} \& \mathrm{E}$} & \multirow{2}{*}{\multicolumn{2}{|c|}{ Prussian blue }} \\
\hline & & \multicolumn{2}{|c|}{$\begin{array}{c}\text { Osteocyte } \\
\text { Nuclei }\end{array}$} & \multicolumn{2}{|c|}{ Marrow Nuclei } & \multicolumn{2}{|c|}{$\begin{array}{c}\text { Marrow } \\
\text { Dehydration }\end{array}$} & \multicolumn{2}{|c|}{ Hemorrhage } & & \\
\hline & & \multicolumn{10}{|c|}{ Time of Dissection } \\
\hline & & 3 days & 6 days & 3 days & 6 days & 3 days & $\begin{array}{l}6 \\
\text { days }\end{array}$ & $\begin{array}{l}3 \\
\text { days }\end{array}$ & $\begin{array}{l}6 \\
\text { days }\end{array}$ & 3 days & 6 days \\
\hline G1 & $\begin{array}{l}6 \text { days } \\
\text { before } \\
\text { death }\end{array}$ & $\begin{array}{c}3.62 \pm 1 \\
.32\end{array}$ & $\begin{array}{c}1.43 \pm 0 \\
.38 *\end{array}$ & $\begin{array}{c}3.89 \pm 1 \\
.54 @\end{array}$ & $\begin{array}{l}1.87 \pm 0 \\
.28 @ *\end{array}$ & $\begin{array}{c}0.64 \pm \\
0.02\end{array}$ & $\begin{array}{l}2.13 \pm \\
0.74 *\end{array}$ & $\begin{array}{c}2.26 \pm \\
1.07 \\
@\end{array}$ & $\begin{array}{c}1.45 \pm \\
0.34 \\
@ *\end{array}$ & $\begin{array}{l}2.35 \pm \\
1.21 @\end{array}$ & $\begin{array}{c}1.87 \pm \\
0.33 \\
@ *\end{array}$ \\
\hline G 2 & $\begin{array}{l}3 \text { days } \\
\text { before } \\
\text { death }\end{array}$ & $\begin{array}{c}2.27 \pm 1 \\
.21 @\end{array}$ & $\begin{array}{l}1.21 \pm 0 \\
.52 @ *\end{array}$ & $\begin{array}{c}2.19 \pm 1 \\
.06 @\end{array}$ & $\begin{array}{l}1.02 \pm 0 \\
.05^{*}\end{array}$ & $\begin{array}{c}0.54 \pm \\
0.03\end{array}$ & $\begin{array}{l}2.01 \pm \\
0.43 *\end{array}$ & $\begin{array}{c}3.34 \pm \\
1.18 \\
@\end{array}$ & $\begin{array}{c}1.77 \pm \\
0.53 \\
@\end{array}$ & $\begin{array}{l}3.43 \pm \\
1.04 @\end{array}$ & $\begin{array}{c}1.89 \pm \\
0.32 \\
@ *\end{array}$ \\
\hline G 3 & $\begin{array}{l}1 \text { days } \\
\text { before } \\
\text { death }\end{array}$ & $\begin{array}{c}1.32 \pm 0 \\
.09 @\end{array}$ & $\begin{array}{l}0.92 \pm 0 \\
.63 @ *\end{array}$ & $\begin{array}{c}2.43 \pm 0 \\
.87 @\end{array}$ & $\begin{array}{l}0.93 \pm 0 \\
.07 @ *\end{array}$ & $\begin{array}{c}0.73 \pm \\
0.05\end{array}$ & $\begin{array}{l}2.78 \pm \\
0.77 *\end{array}$ & $\begin{array}{c}3.95 \pm \\
1.21 \\
@\end{array}$ & $\begin{array}{c}1.89 \pm \\
0.63 \\
@ *\end{array}$ & $\begin{array}{l}3.87 \pm \\
1.02 @\end{array}$ & $\begin{array}{c}2.13 \pm \\
0.78 \\
@ *\end{array}$ \\
\hline G 4 & $\begin{array}{l}12 \mathrm{hrs} \\
\text { before } \\
\text { death }\end{array}$ & $\begin{array}{c}3.32 \pm . \\
1.61\end{array}$ & $\begin{array}{c}1.40 \pm 0 \\
.23 *\end{array}$ & $\begin{array}{c}3.02 \pm 1 \\
.04 @\end{array}$ & $\begin{array}{l}1.35 \pm 0 \\
.03 @ *\end{array}$ & $\begin{array}{c}0.45 \pm \\
0.04\end{array}$ & $\begin{array}{l}2.64 \pm \\
0.68 *\end{array}$ & $\begin{array}{c}3.84 \pm \\
1.53 \\
@\end{array}$ & $\begin{array}{c}1.65 \pm \\
0.34 \\
@ *\end{array}$ & $\begin{array}{l}3.68 \pm \\
1.04 @\end{array}$ & $\begin{array}{c}2.11 \pm \\
0.52 \\
@ *\end{array}$ \\
\hline G 5 & $\begin{array}{l}\text { Just before } \\
\text { death }\end{array}$ & $\begin{array}{c}3.25 \pm . \\
1.03\end{array}$ & $\begin{array}{c}1.42 \pm 0 \\
.41 *\end{array}$ & $\begin{array}{c}2.67 \pm 1 \\
.07 @\end{array}$ & $\begin{array}{c}1.07 \pm 0 \\
.03 *\end{array}$ & $\begin{array}{c}0.32 \pm \\
0.03\end{array}$ & $\begin{array}{l}2.62 \pm \\
0.89 *\end{array}$ & $\begin{array}{c}2.87 \pm \\
1.05 \\
@ \\
\end{array}$ & $\begin{array}{c}1.01 \pm \\
0.43 \\
@ * \\
\end{array}$ & $\begin{array}{c}0.65 \pm \\
0.94\end{array}$ & $\begin{array}{l}0.36 \pm \\
0.63 *\end{array}$ \\
\hline G 6 & $\begin{array}{c}2 \text { hrs after } \\
\text { death }\end{array}$ & $\begin{array}{c}3.37 \pm 1 \\
.52\end{array}$ & $\begin{array}{c}1.45 \pm 0 \\
.31 *\end{array}$ & $\begin{array}{c}2.03 \pm 0 \\
.64\end{array}$ & $\begin{array}{c}1.03 \pm 0 \\
.04 *\end{array}$ & $\begin{array}{c}0.35 \pm \\
0.04\end{array}$ & $\begin{array}{l}2.11 \pm \\
0.77 *\end{array}$ & $\begin{array}{c}0.13 \pm \\
0.04\end{array}$ & $\begin{array}{c}0.11 \pm \\
0.03\end{array}$ & $\begin{array}{c}0.54 \pm \\
0.05\end{array}$ & $\begin{array}{l}0.21 \pm \\
0.06^{*}\end{array}$ \\
\hline
\end{tabular}

For each animal, the score was calculated as the average of results from the examined 3 visual fields for the 3 slides. For each subgroup, data were expressed as mean \pm SD.

Score key: for osteocytes and bone marrow nuclei: " 1 " indicates $0-25 \%$ visible nuclei, "2" indicates $25-50 \%$ visible nuclei, " 3 " indicates $50-75 \%$, and " 4 " indicates $75-100 \%$ visible nuclei. For marrow dehydration: " 1 " indicates no dehydration, " 2 " indicates moderate dehydration, and " 3 " indicates pronounced dehydration.

For hemorrhage: "1" indicates no hemorrhage, "2" indicates mild hemorrhage, " 3 " indicates moderate hemorrhage, and "4" indicates marked hemorrhage.

For Prussian blue: " 1 " indicates absent stain, "2" indicates mild amount of stained area, " 3 " indicates moderate amount, and " 4 " indicates pronounced stained area.

@ Significant in comparing with $2 \mathrm{~h}$ postmortem fracture group.

* Significant in comparing with 3 days postmortem dissection of the same time of fracture. 
Table 2: quantitative assessment of different histopathological parameters in slides stained with Masson Trichrome stains.

\begin{tabular}{|c|c|c|c|c|c|c|c|c|c|}
\hline \multirow{4}{*}{$\begin{array}{c}\text { Animal } \\
\text { S } \\
\text { Group }\end{array}$} & \multirow{4}{*}{$\begin{array}{l}\text { Time of } \\
\text { bone } \\
\text { fracture }\end{array}$} & \multicolumn{8}{|c|}{ Stain Affinity Score } \\
\hline & & \multicolumn{2}{|c|}{$\begin{array}{c}\text { Osteocyte } \\
\text { Nuclei }\end{array}$} & \multicolumn{2}{|c|}{$\begin{array}{l}\text { Marrow } \\
\text { Nuclei }\end{array}$} & \multicolumn{2}{|c|}{$\begin{array}{c}\text { Marrow } \\
\text { Dehydration }\end{array}$} & \multicolumn{2}{|c|}{ Hemorrhage } \\
\hline & & \multicolumn{8}{|c|}{ Time of Dissection } \\
\hline & & $\begin{array}{l}3 \\
\text { days }\end{array}$ & 6 days & $\begin{array}{l}3 \\
\text { days }\end{array}$ & $\begin{array}{l}6 \\
\text { days }\end{array}$ & $\begin{array}{l}3 \\
\text { days }\end{array}$ & 6 days & 3 days & 6 days \\
\hline G1 & $\begin{array}{l}6 \text { days } \\
\text { before } \\
\text { death }\end{array}$ & $\begin{array}{c}3.45 \\
\pm 1.4 \\
3\end{array}$ & $\begin{array}{l}1.76 \pm \\
0.68 *\end{array}$ & $\begin{array}{c}3.77 \pm \\
1.54 \\
@\end{array}$ & $\begin{array}{c}1.98 \pm \\
0.56 \\
@ *\end{array}$ & $\begin{array}{c}0.76 \pm \\
0.33\end{array}$ & $\begin{array}{c}2.65 \pm 0 \\
.87 *\end{array}$ & $\begin{array}{c}2.33 \pm 1 . \\
74 @\end{array}$ & $\begin{array}{c}1.46 \pm 0.5 \\
4 @ *\end{array}$ \\
\hline G 2 & $\begin{array}{l}3 \text { days } \\
\text { before } \\
\text { death }\end{array}$ & $\begin{array}{c}2.43 \\
\pm 1.5 \\
4 @\end{array}$ & $\begin{array}{c}1.25 \pm \\
0.76 @ \\
*\end{array}$ & $\begin{array}{c}2.34 \pm \\
1.54 \\
@\end{array}$ & $\begin{array}{c}1.44 \pm \\
0.14\end{array}$ & $\begin{array}{c}0.53 \pm \\
0.07\end{array}$ & $\begin{array}{c}2.76 \pm 0 \\
.76 *\end{array}$ & $\begin{array}{c}3.65 \pm 1 . \\
65 @\end{array}$ & $\begin{array}{c}1.52 \pm 0.5 \\
1 @ *\end{array}$ \\
\hline G 3 & $\begin{array}{l}1 \text { days } \\
\text { before } \\
\text { death }\end{array}$ & $\begin{array}{c}1.65 \\
\pm 0.2 \\
1 @\end{array}$ & $\begin{array}{r}1.22 \pm \\
0.66 @\end{array}$ & $\begin{array}{c}2.54 \pm \\
0.99 \\
@\end{array}$ & $\begin{array}{c}0.99 \pm \\
0.16 \\
@ *\end{array}$ & $\begin{array}{c}0.85 \pm \\
0.12\end{array}$ & $\begin{array}{l}2.73 \pm 0 \\
.45 @ *\end{array}$ & $\begin{array}{c}3.76 \pm 1 . \\
34 @\end{array}$ & $\begin{array}{c}1.84 \pm 0.6 \\
7 @ *\end{array}$ \\
\hline G 4 & $\begin{array}{l}12 \mathrm{hrs} \\
\text { before } \\
\text { death }\end{array}$ & $\begin{array}{c}3.43 \\
\pm .1 .7 \\
6\end{array}$ & $\begin{array}{l}1.76 \pm \\
0.43 *\end{array}$ & $\begin{array}{c}3.65 \pm \\
1.54 \\
@\end{array}$ & $\begin{array}{c}1.65 \pm \\
0.34 \\
@ *\end{array}$ & $\begin{array}{c}0.64 \pm \\
0.05\end{array}$ & $\begin{array}{c}2.75 \pm 0 \\
.87 *\end{array}$ & $\begin{array}{c}3.54 \pm 1 . \\
43 @\end{array}$ & $\begin{array}{c}1.65 \pm 0.3 \\
6 @ *\end{array}$ \\
\hline G 5 & $\begin{array}{l}\text { Just before } \\
\text { death }\end{array}$ & $\begin{array}{c}3.67 \\
+.1 .2 \\
2\end{array}$ & $\begin{array}{l}1.83 \pm \\
0.53 *\end{array}$ & $\begin{array}{c}2.87 \pm \\
1.54 \\
@\end{array}$ & $\begin{array}{c}1.65 \pm \\
0.23 \\
@ *\end{array}$ & $\begin{array}{c}0.35 \pm \\
0.02\end{array}$ & $\begin{array}{c}2.34 \pm 0 \\
.71 *\end{array}$ & $\begin{array}{c}2.88 \pm 1 . \\
22 @\end{array}$ & $\begin{array}{c}1.61 \pm 0.4 \\
6 @ *\end{array}$ \\
\hline G 6 & $\begin{array}{c}2 \text { hrs after } \\
\text { death }\end{array}$ & $\begin{array}{c}3.43 \\
\pm 1.6 \\
4\end{array}$ & $\begin{array}{l}1.66 \pm \\
0.53 *\end{array}$ & $\begin{array}{c}2.44 \pm \\
0.67\end{array}$ & $\begin{array}{l}1.44 \pm \\
0.54 *\end{array}$ & $\begin{array}{c}0.36 \pm \\
0.07\end{array}$ & $\begin{array}{c}2.65 \pm 0 \\
.83 *\end{array}$ & $\begin{array}{c}0.43 \pm 0 \\
06\end{array}$ & $\begin{array}{c}0.16 \pm 0.0 \\
6 *\end{array}$ \\
\hline
\end{tabular}

For each animal, the score was calculated as the average of results from the examined 3 visual fields for the 3 slides. For each subgroup, data were expressed as mean \pm SD.

Score key: for osteocytes and bone marrow nuclei: " 1 " indicates $0-25 \%$ visible nuclei, "2" indicates $25-50 \%$ visible nuclei, " 3 " indicates 50-75\%, and " 4 " indicates $75-100 \%$ visible nuclei. For marrow dehydration: " 1 " indicates no dehydration, " 2 " indicates moderate dehydration, and " 3 " indicates pronounced dehydration.

For hemorrhage: " 1 " indicates no hemorrhage, " 2 " indicates mild hemorrhage, " 3 " indicates moderate hemorrhage, and " 4 " indicates marked hemorrhage.

@ Significant in comparing with $2 \mathrm{~h}$ postmortem fracture group.

* Significant in comparing with 3 days postmortem dissection of the same time of fracture. 


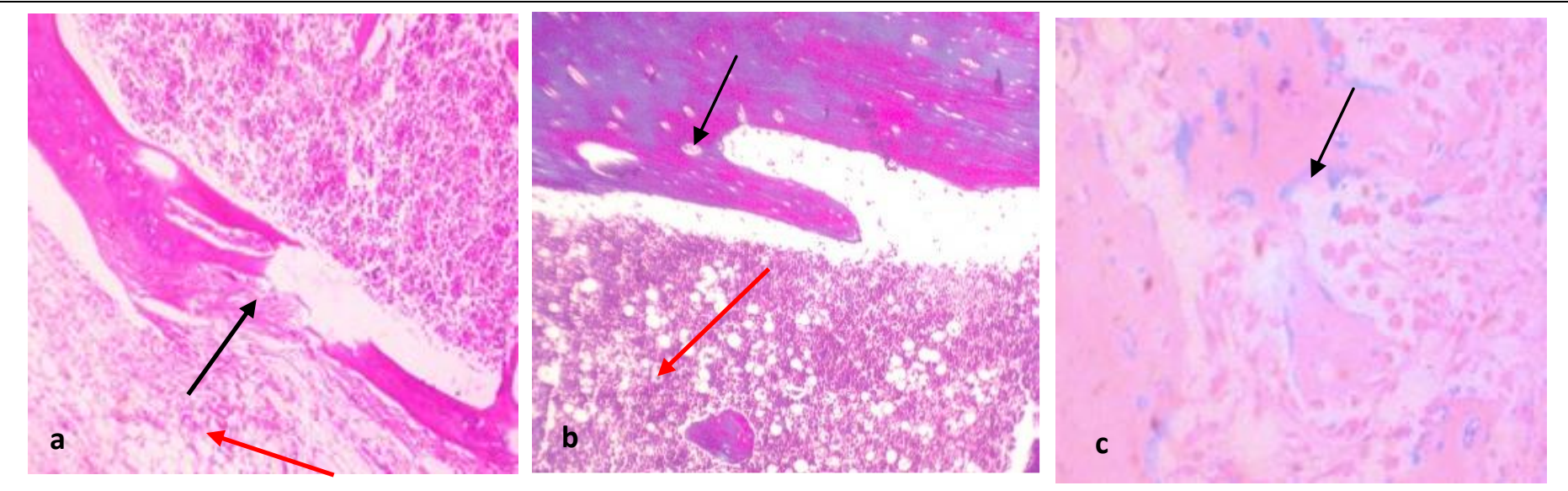

Fig. (1) Photomicrograph of a longitudinal section of bone tissue of rat femora fractured 6 days antemortem and examined 3 days postmortem showing: (a) fibrous callus tissue (black arrow) and marked bone marrow cells (red arrow) (H\&E) (b) visible osteocyte (black arrow) and bone marrow nuclei (red arrow) (trichrome stain) (c) bluish hemosiderin deposits (Prussian blue) (arrow) (x200).

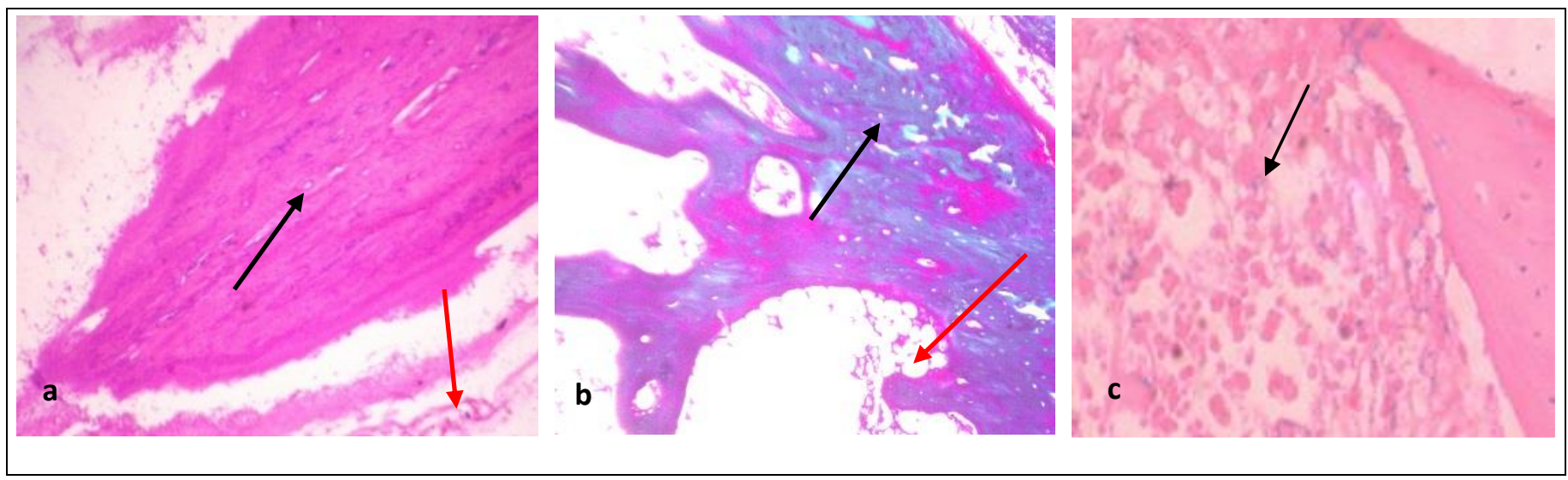

Fig. (2) Photomicrograph of a longitudinal section of bone tissue of rat femora fractured 6 days antemortem and examined 6 days postmortem showing: (a) (H\&E) \& (b) (trichrome stain) autolysis of an inner osteogenic layers that represented as empty lacunar spaces (black arrow) and clear marrow space ( red arrow). (c) Bluish hemosiderin deposits (Prussian blue) (arrow) (X 200). 


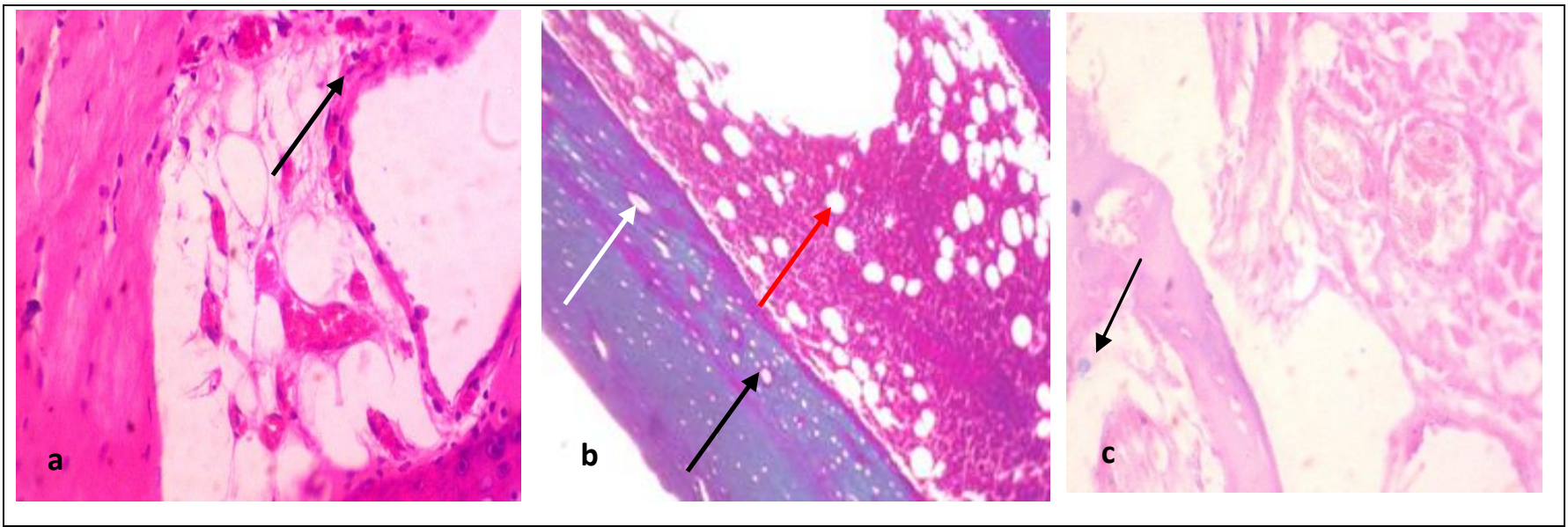

Fig. (3): Photomicrograph of a longitudinal section of bone tissue of rat femora fractured 3 days antemortem and examined 3 days postmortem showing (a) development of granulation tissue (arrow) (H\&E) (b some visible (white arrow) and empty (black arrow) osteocyte nuclei and empty bone marrow nuclei (red arrow) (trichrome) (c) visible few hemosiderin deposits (black arrow) (Prussian blue) (X 200).

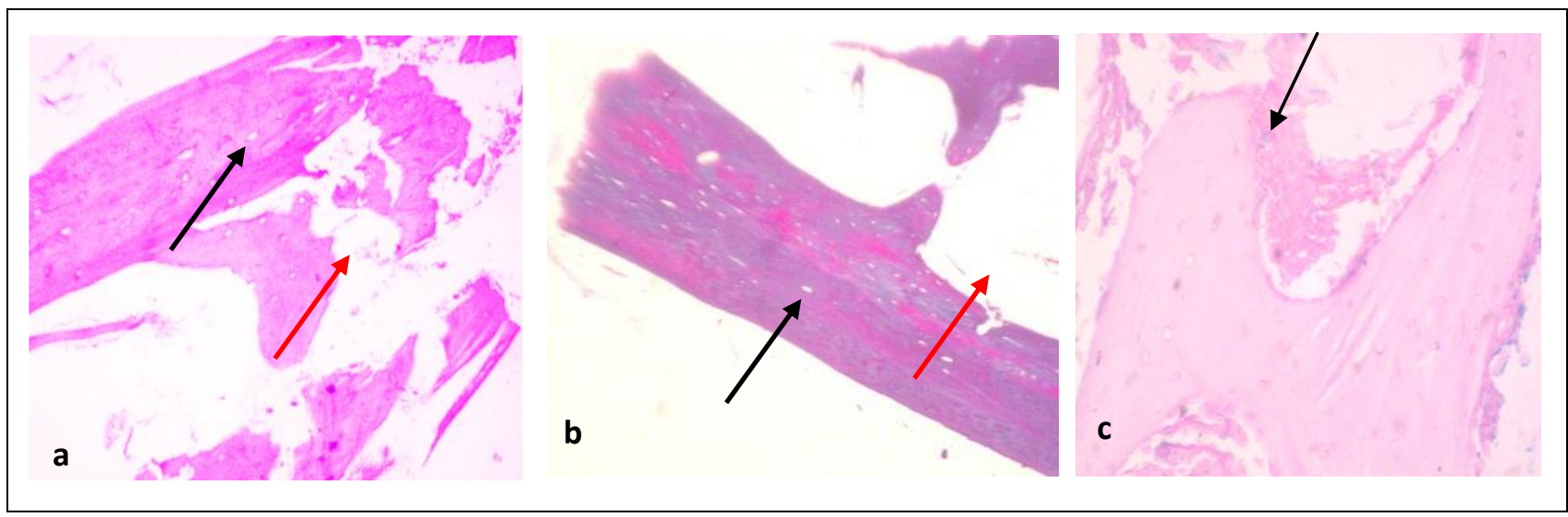

Fig. (4): Photomicrograph of a longitudinal section of bone tissue of rat femora fractured 3 days antemortem and examined 6 days postmortem showing(a) (H\&E) \& (b) (trichrome stain) autolysis of an inner osteogenic layers that represented as empty lacunar spaces (black arrow) and clear marrow space (red arrow) Trichrome (c) Some few hemosiderin deposits (Prussian blue) (X 200). 


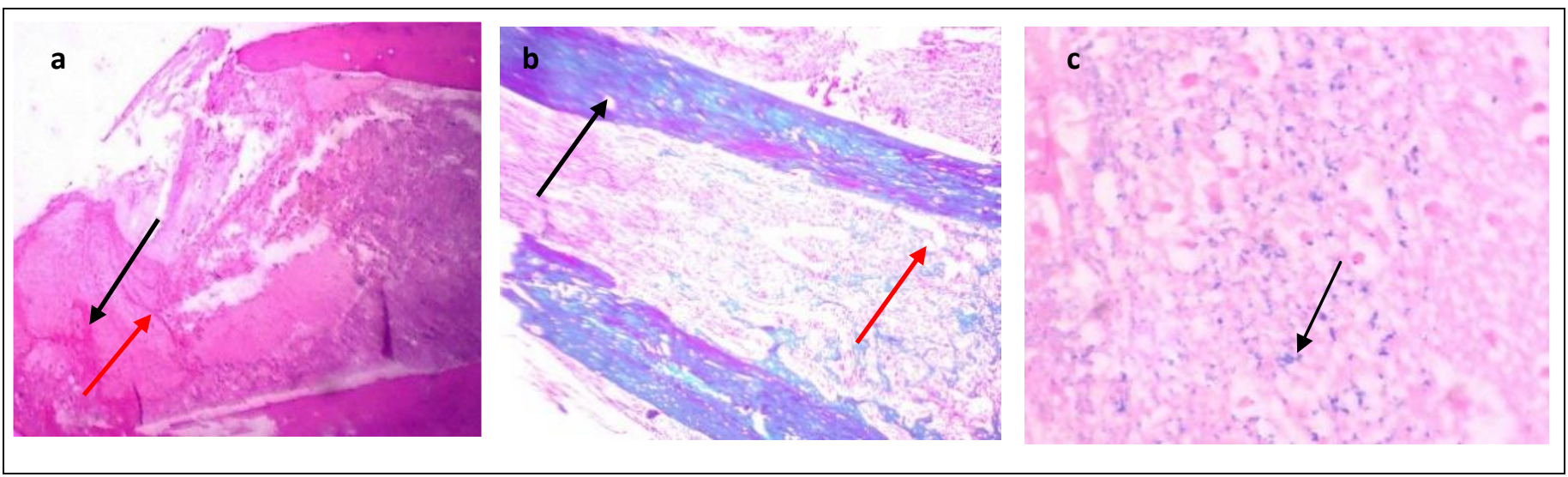

Fig. (5): Photomicrograph of a longitudinal section of bone tissue of rat femora fractured 1 day antemortem and examined 3 days postmortem showing (a) hemorrhage (black arrow) and fibrin deposition (red arrow) (H\&E) (b) clear marrow (red arrow) and osteocytic cells (black arrow) (trichrome stain) (c) Presence of an increased number of hemosiderin deposits (arrow) (Prussian blue) (X 200).

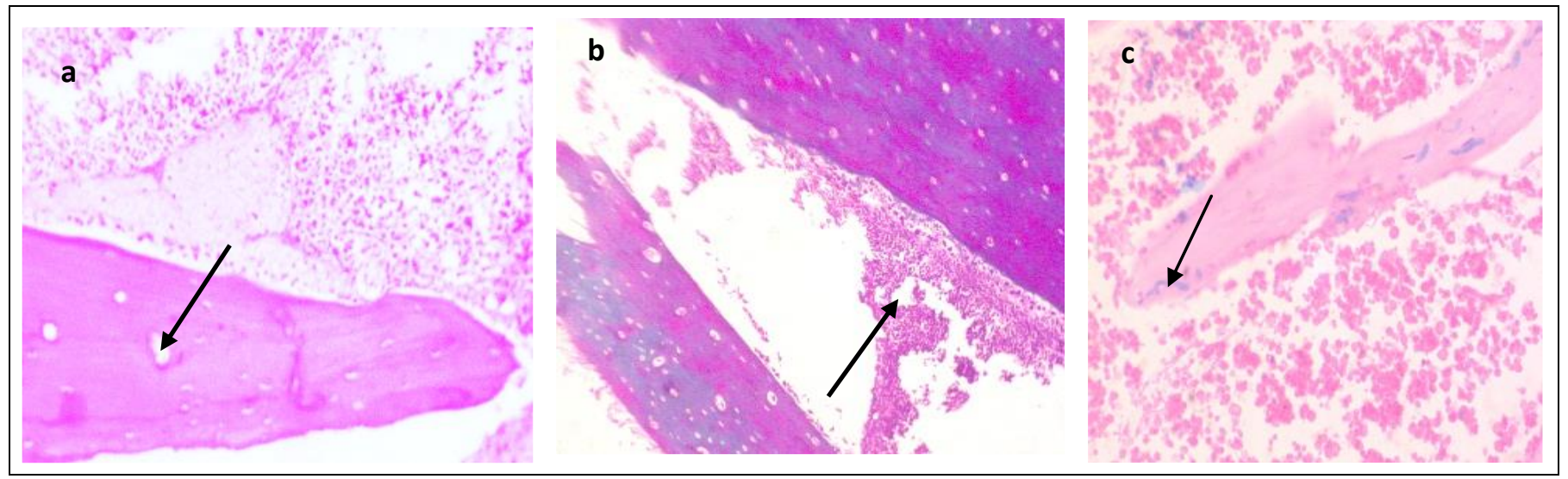

Fig. (6): Photomicrograph of a longitudinal section of bone tissue of rat femora fractured 1 day antemortem and examined 6 days postmortem showing (a) autolytic changes of bone marrow and empty of some lacunar spaces (arrow) (H\&E) (b) Slight marrow dehydration (arrow) (trichrome stain) (c) very few hemosiderin deposits were seen (arrow) (Prussian blue) (X 200). 

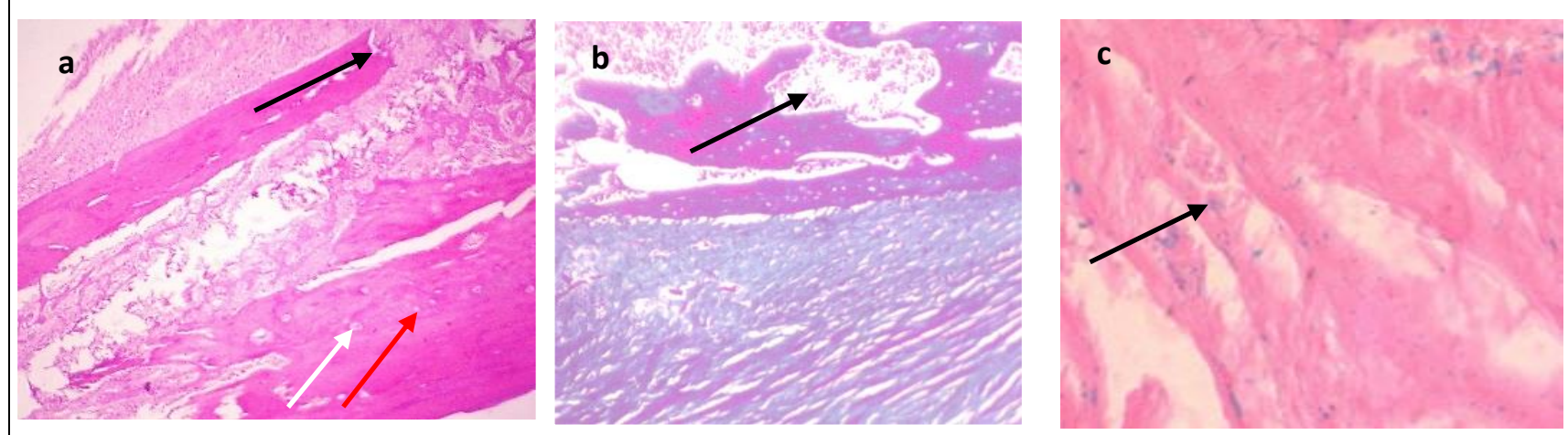

Fig. (7): Photomicrograph of a longitudinal section of bone tissue of rat femora fractured $12 \mathrm{~h}$ antemortem and examined 3 days postmortem showing (a) hemorrhage (black arrow), visible (white arrow), and non-visible (red arrow ) osteocyte nuclei (H\&E) (b) Slight marrow dehydration (arrow) Trichrome (c) Few hemosiderin deposits (arrow) (Prussian blue) (X 200).

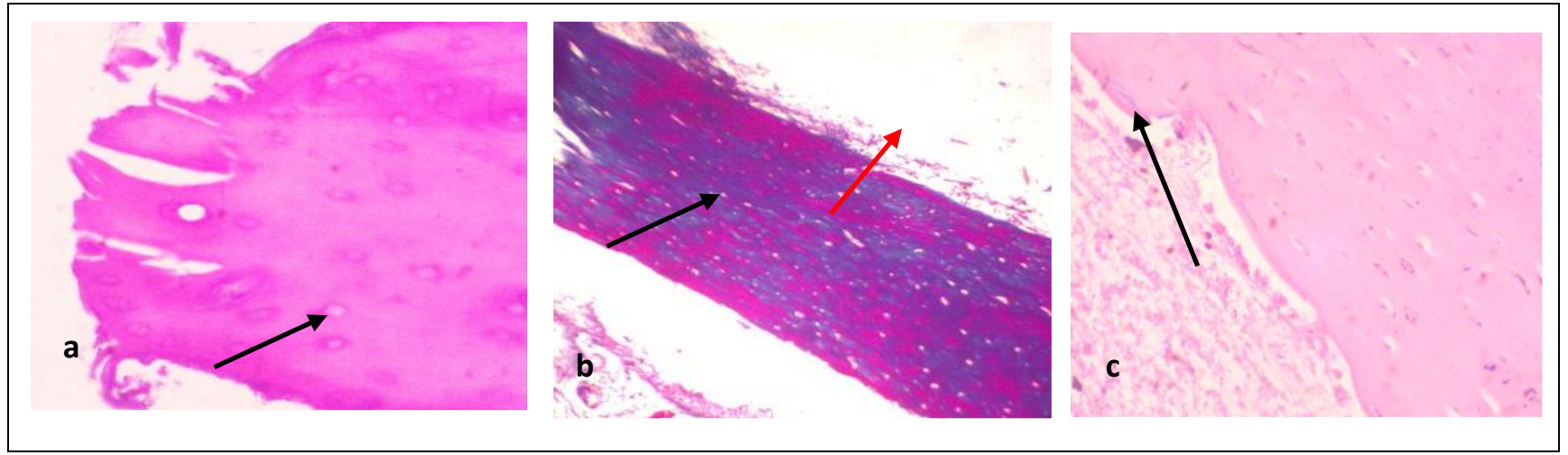

Fig. (8): Photomicrograph of a longitudinal section of bone tissue of rat femora fractured $12 \mathrm{~h}$ antemortem and examined 6 days postmortem showing: (a) (H\&E) \& (b) (trichrome stain) autolysis of an inner osteogenic layers that represented as empty lacunar spaces(black arrow) and clear marrow space (red arrow) (c) Minimal hemosiderin deposits were noticed (black arrow) (Prussian blue) (X 200). 

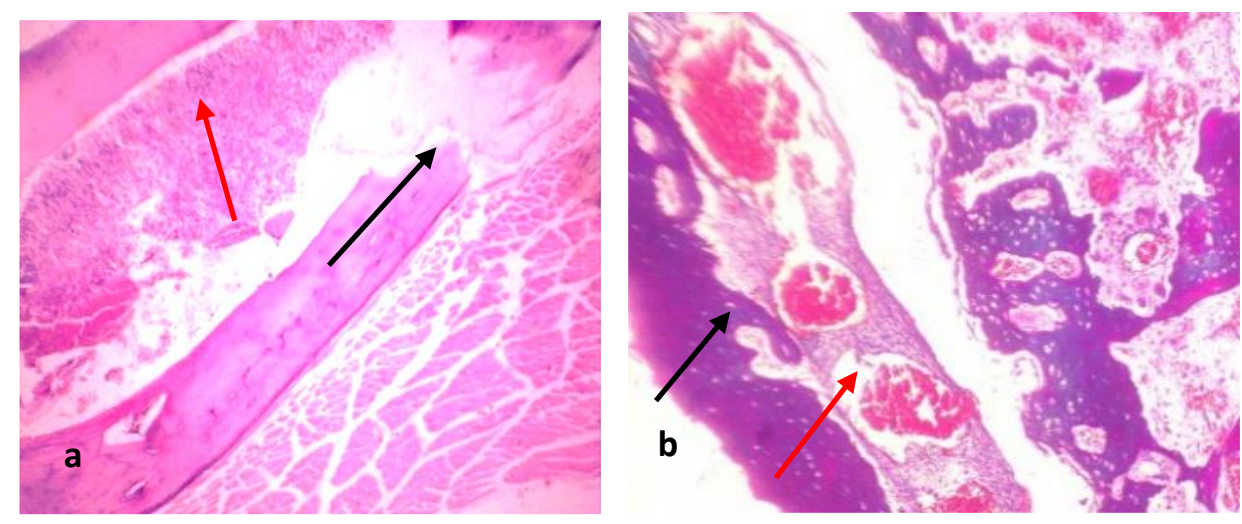

Fig. (9): Photomicrograph of a longitudinal section of bone tissue of rat femora fractured $2 \mathrm{~h}$ antemortem and examined 3 days postmortem showing: (a) fracture line (black arrow) and hemorrhage (red arrow) (H\&E) (b) Empty some lacunar spaces (black arrow) and clear marrow space (red arrow) (trichrome satin) (c) Absent of hemosiderin deposits (Prussian blue) (X 200).
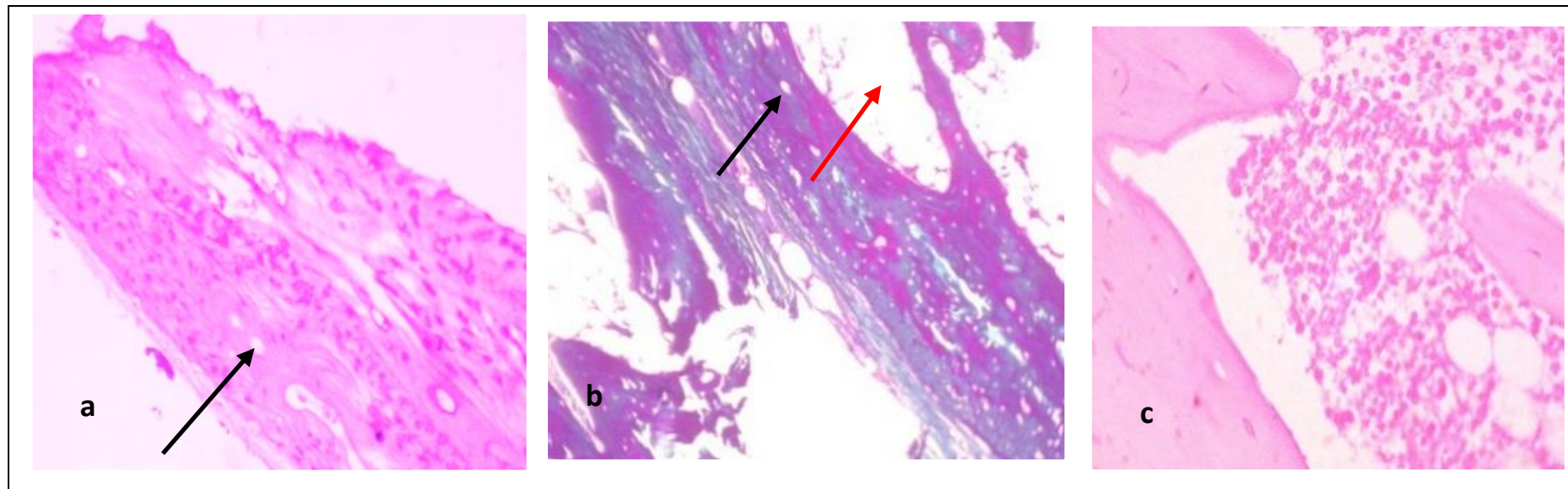

Fig. (10): Photomicrograph of a longitudinal section of bone tissue of rat femora fractured $2 \mathrm{~h}$ antemortem and examined 6 days postmortem showing: (a) (H\&E) \& (b) (trichrome satin) autolysis of an inner osteogenic layers that represented as empty lacunar spaces (black arrow) and clear marrow space (red arrow) (c) Absence of hemosiderin deposits (Prussian blue) (X 200). 


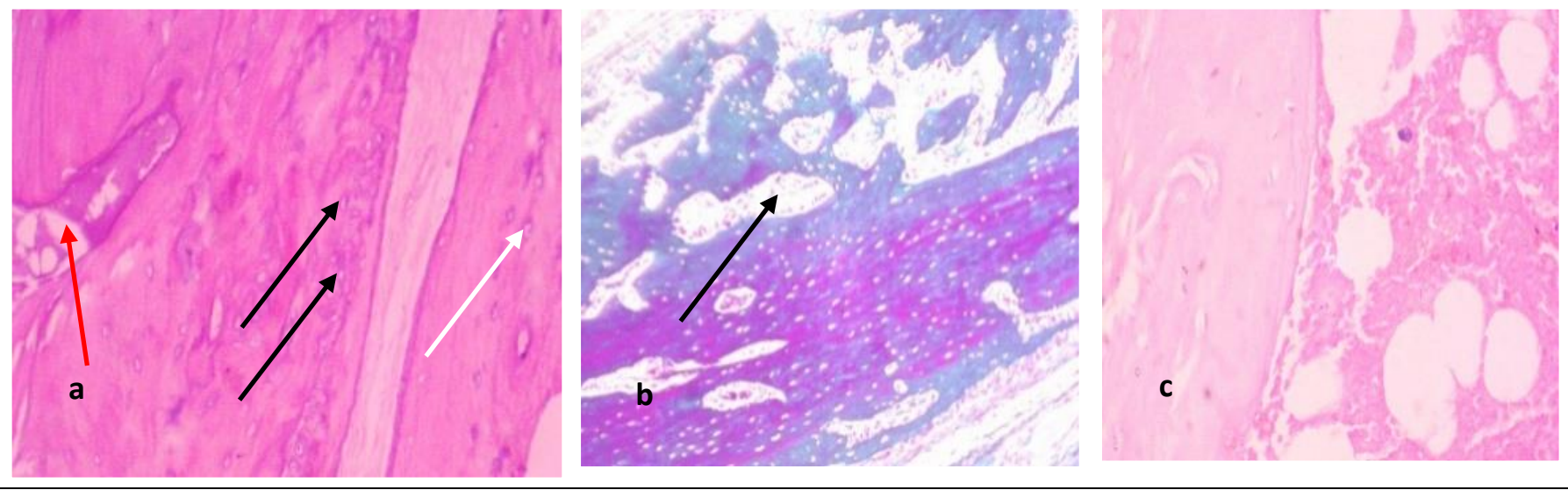

Fig. (11): Photomicrograph of a longitudinal section of bone tissue of rat femora fractured $2 \mathrm{~h}$ postmortem and examined 3 days postmortem showing: (a) Absent hemorrhage, non-visible (black arrows) and visible (white arrow) osteocyte nuclei, and empty bone marrow spaces (red arrow) (H\&E) (b) Slight marrow dehydration (arrow) (trichrome stain) (c) Absent of hemosiderin deposits (Prussian blue) (X 200).

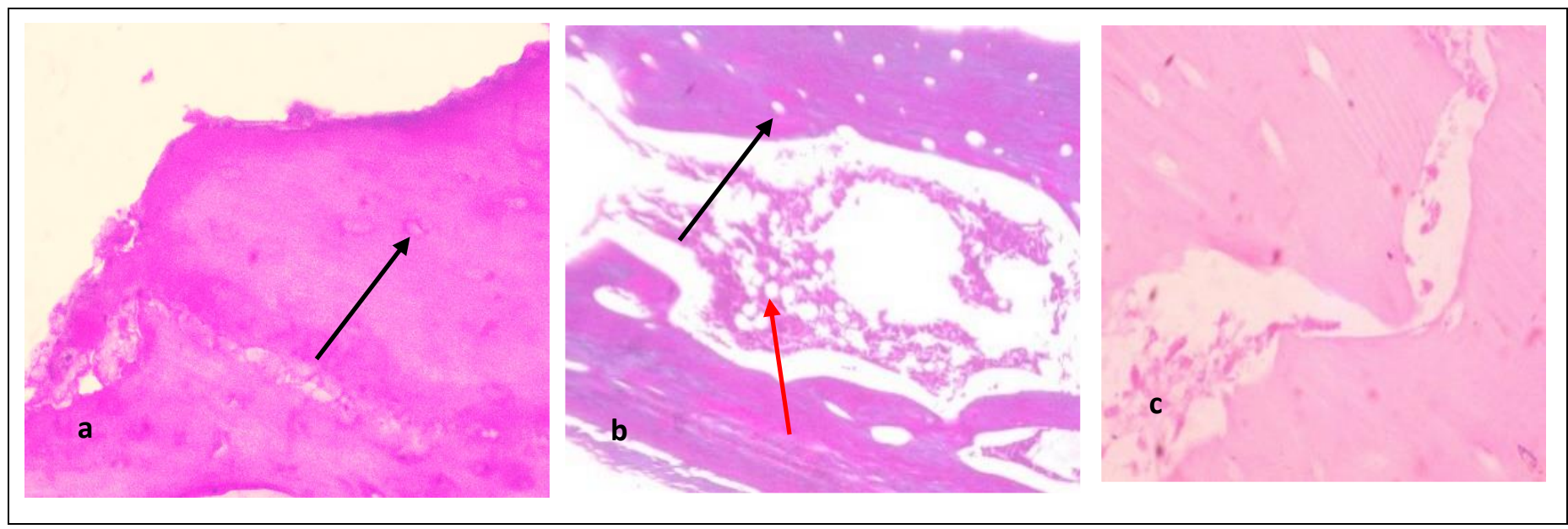

Fig. (12): Photomicrograph of a longitudinal section of bone tissue rat femora fractured $2 \mathrm{~h}$ postmortem and examined 6 days postmortem showing: (a) autolytic changes of bone marrow (arrow) (H\&E) (b) Slight marrow dehydration (red arrow) and empty lacunar spaces (black arrow) (trichrome stain) (c) Absent of hemosiderin deposit (Prussian blue) (X 200). 


\section{DISCUSSION}

The diagnosis and differentiation between antemortem or postmortem skin wound and estimation of the wound age have been thoroughly investigated with accurate results have been obtained regarding this context (Ishida et al., 2018). In contrast, skeletal trauma is just classified as healing or healed fracture without much detailed. Accurate dating of antemortem injury is of great value for forensic anthropologists (Boer et al., 2015).

Furthermore, the differentiation between antemortem, perimortem and postmortem bone fracture is difficult to perform (Cappella et al., 2014, Jordana et al., 2013). Mostly, it depends on macro-morphological characters of the fracture such as fracture angle and fracture surface or edge. While these morphological characters may be altered by several environmental factors which make the process of differentiation more difficult and complicated (Pechníková et al., 2011).
In the present study, histopathological techniques with multiple stains were used for enhanced clarification of different microscopic structures of the bone fracture to estimate the age of injury at different postmortem intervals. Our results revealed that hemorrhage was more evidenced in 1day fracture, followed by 3 days and 12 hours, while, less in 6 days and at time of death. It was absent in postmortem fracture. These findings appeared from $\mathrm{H} \& \mathrm{E}$, trichrome, and Prussian blue stains. Prussian blue stain of hemosiderin was more evident at 6 days postmortem autopsy than H\&E and trichrome. These findings are in agreement with (Powell, 2015) who revealed that the amount of hemorrhage appeared at 1-day survival time was more than at the time of death. McKinley et al., (2014) reported that the amount of hemorrhage is directly proportional to the time in the first day after the injury. Cattaneo et al., (2010) found a blood clot in bone fracture that occurred $34 \mathrm{~min}$. before death.

Fibrous callous formation was evident at 6 days before death and 
fibroblasts proliferation with the development of granulation tissue appeared at 3 days before death. These findings are consistent with the process of healing proved by Dettmeyer (Dettmeyer, 2018). Two factors affect changes in the cellular components at the fracture site. The first is the vital reactions that the bone does to heal fracture. The second is the postmortem autolytic changes occur in the tissues after death (Goff, 2010). Both should be taken into account in looking at the changes that occur at different healing stages in the two chosen postmortem periods.

Bone marrow nuclei and the degree of bone marrow dehydration were more affected by the time of autopsy. Rapid autolysis occurred when comparing these parameters at 6 days postmortem examination with the same group at 3 days analysis. Sorg and Haglund, (2002) proved that bone marrow cells have a high metabolic rate as the same as erythrocytes, hence, they undergo rapid degradation.
Usually, in bone healing (2-3 days post fracture), empty lacunar spaces are evident due to death of osteocytes; the clear line between dead bone (empty lacunae) and live bone appeared (Dettmeyer, 2018). Most of the examined bone sections showed significant decreases in the number of osteocyte and bone marrow nuclei, bone marrow hydration, and Prussian blue when examined at 6 days postmortem in comparing with 3 days postmortem. Powell (2015) revealed that the number of visible nuclei decreased gradually over time. These changes result from the normal autolytic changes occur after cellular death. These changes could be of a value in the estimation of postmortem interval from histopathological examination of bone tissue. Although the examined bone sections in this study were limited to that close to the fracture site, Powell (2015) found that fracture and non-fracture bone tissues decompose in a similar manner.

$\mathrm{H} \& \mathrm{E}$ and trichrome stain were beneficial in the estimation of the age of the long bone fracture and differentiation 
between antemortem, perimortem and postmortem fracture, while Prussian blue stain showed insignificant changes in fracture produced just before death. This could be explained as the hemoglobin, which is released from ingested erythrocytes by phagocytosis, undergoes degradation into hemosiderin which is condensed in and around the phagocytic cell. The Prussian blue stained remote hemorrhage that undergone a phagocytic process which did not have time to occur in injuries inflicted shortly before circulatory cessation (Dettmeyer, 2018). These changes could be seen in putrefied bone in late postmortem interval ( 3 and 6 days postmortem in hot weather).

Several biomechanical and pathological factors could disturb healing of bone fracture; for example, the type and site of fracture and, the presence or absence of therapeutic intervention (immobilization). Other general factors include the age of the victim, general diseases, and nutritional condition (Mirhadi et al., 2013). In this study, immobilized non-displaced fracture only was studied.

\section{CONCLUSION}

The present study succeeded in the estimation of the age of the long bone fracture and differentiation of events that occurred antemortem from perimortem and postmortem fracture. Further work is needed to clarify more information about the degree of bone autolysis over more repeated periods with a larger sample size under different environmental conditions. Other factors (biomechanical and pathological) are needed to elucidate in further work (the difference between rat and human). More advanced stains are recommended for more specific structures.

\section{ACKNOWLEDGMENT}

The authors thank Prof. Dr. Ahmed Hassan Osman, Professor of Pathology, Pathology Department, Cairo University for his great help in the histopathological study in this work

\section{Funding}

No funds were received.

\section{Conflict of interest}

No conflicts of interest. 


\section{REFERENCES}

Boer, H.; Merwe, A.; Hammer, S.; Steyn, M. And Maat, G. (2015): Assessing Post- Traumatic Time Interval In Human Dry Bone. International Journal Of Osteoarchaeology, 25: 98-109.

Cappella, A.; Amadasi, A.; Castoldi, E.; Mazzarelli, D.; Gaudio, D. And Cattaneo, C. (2014): The Difficult Task Of Assessing Perimortem And Postmortem Fractures On The Skeleton: A Blind Text On 210 Fractures Of Known Origin. Journal Of Forensic Sciences, 59: 15981601.

Cattaneo, C.; Andreola, S.; Marinelli, E.; Poppa, P.; Porta, D. And Grandi, M. (2010): The Detection Of Microscopic Markers Of Hemorrhaging And Wound Age On Dry Bone: A Pilot Study. The American Journal Of Forensic Medicine And Pathology, 31: 22-26.

Christensen Am, Passalacqua Nv And Bartelink EJ. Forensic
Anthropology: Current Methods

And Practice. Elsevier 2014;19-

53.

Dettmeyer RB. Vitality, Injury Age, Determination Of Skin Wound Age, And Fracture Age. In:

Forensic Histopathology:

Fundamentals And Perspectives, 2nd Ed. Springer International Publishing AG, Switzerland 2018;241-264.

El-Noor, M. M.A.; Elgazzar, F.M. And Alshenawy, H.A. (2017): Role Of Inducible Nitric Oxide Synthase And Interleukin-6 Expression In Estimation Of Skin Burn Age And Vitality. Journal Of Forensic And Legal Medicine, 52: 148-153.

Galloway A, Zephro L, Wedel VL. Diagnostic Criteria For The Determination Of Timing And Fracture Mechanism. In: Broken Bones. Anthropological Analysis Of Blunt Force Trauma. Springfield 2014;47-58.

George, J.; Van Wettere, A.J.; Michaels, B.B.; Crain, D. and 
Lewbart,

G.A.

(2016):

Histopathologic Evaluation Of

Postmortem Autolytic Changes In

Bluegill (Lepomis Macrohirus)

And Crappie (Pomoxis Anularis)

At Varied Time Intervals And

Storage Temperatures. Peerj, 4, E1943.

Goff ML. Early Postmortem Changes And Stages Of Decomposition. In: Current Concepts In Forensic Entomology. Springer Dordrecht Heidelberg London NY 2010;124.

Handool, K.O.; Ibrahim, S.M.; Kaka, U.; Omar, M.A.; Abu, J.; Yusoff, M.S.M. Et Al. (2018): Optimization Of A Closed Rat Tibial Fracture Model. Journal Of Experimental Orthopaedics, 5: 13. Ishida, Y.; Kuninaka, Y.; Furukawa, F.; Kimura, A.; Nosaka, M.; Fukami, M.; Et Al. (2018): Immunohistochemical Analysis On Aquaporin-1 And Aquaporin3 In Skin Wounds From The Aspects Of Wound Age Determination. International
Journal Of Legal Medicine, 132: 237-242.

Jordana, F.; Colat- Parros, J. And Bénézech, M. (2013): Diagnosis Of Skull Fractures According To Postmortem Interval: An Experimental Approach In A Porcine Model. Journal Of Forensic Sciences, 58.

Karr, L.P. And Outram, A.K. (2012): Tracking Changes In Bone Fracture Morphology Over Time: Environment, Taphonomy, And The Archaeological Record. Journal Of Archaeological Science, 39:555-559.

Karr, L.P. And Outram, A.K. (2015): Bone Degradation And Environment: Understanding, Assessing And Conducting Archaeological Experiments Using Modern Animal Bones. International Journal Of Osteoarchaeology, 25: 201-212.

Mckinley MP, O'Loughlin VD, Pennefather-O'Brien E, Harris RT. Human Anatomy. $4^{\text {th }}$ ed. 
Mcgraw-Hill Higher Education

Boston, MA 2014.

Mirhadi, S.; Ashwood, N. And Karagkevrekis, B. (2013): Factors Influencing Fracture Healing. Trauma, 15: 140-155.

Nosaka, M.; Ishida, Y.; Kimura, A.; Kawaguchi, T.; Yamamoto, H.; Kuninaka, Y. Et Al. (2017): Immunohistochemical Detection Of Intrathrombotic Fibrocytes And Its Application To Thrombus Age Estimation In Murine Deep Vein Thrombosis Model. International Journal Of Legal Medicine, 131: 179-183.

Pechníková, M.; Porta, D. And Cattaneo, C. (2011):

Distinguishing Between Perimortem And Postmortem Fractures: Are Osteons Of Any Help? International Journal Of Legal Medicine, 125: 591.

Powell, J.W. (2015): Multiple Stain Histology Of Skeletal Fractures: Healing And Microtaphonomy, University Of South Florida. .
Http://Scholarcommons.Usf.Edu/ Etd/5835

Scheirs, S.; Malgosa, A.; SanchezMolina, D.; Ortega-Sánchez, M.; Velázquez-Ameijide, J.; Arregui-Dalmases, C.; Et Al. (2017): New Insights In The Analysis Of Blunt Force Trauma In Human Bones. Preliminary Results. International Journal Of Legal Medicine, 131: 867-875.

Sorg MH, Haglund WD. Advances in Forensic Taphonomy: methods, theory and archeological perspectives. The Postmortem Fate Of Human Remains, CRC Press 2002; 46-55.

Sun, J.H.; Zhu，X.Y.; Dong，T.N.; Zhang, X.H.; Liu, Q.Q.; Li, S.Q. And Du, Q.X. (2017a): An "Up, No Change, Or Down" System: Time-Dependent Expression Of Mrnas In Contused Skeletal Muscle Of Rats Used For Wound Age Estimation. Forensic Science International, 272: 104-110.

Sun, J.H.; Zhu, X.Y.; Dong, T.N.; Li, S.Q. And Du, Q.X. (2017b): 
Measuring Temporal Expression, Systematic Response, And PostMortem Stability To Assess Potential Markers For Estimating Wound Age: An Example Of Fosl1 In Contused Skeletal Muscle. Australian Journal of Forensic Sciences, 1-13.

Suvarna KS, Layton C, Bancroft JD. Bancroft's Theory And Practice Of Histological Techniques. $8^{\text {th }}$ ed. Elsevier Health Sciences 2018;126-138.

Wedel VL, Galloway A. Broken Bones: Anthropological Analysis Of Blunt Force Trauma. $2^{\text {nd }}$ ed. Charles C Thomas Publisher 2013; 49-58. 


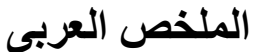

التمييز بين كسور العظام قبل، و أثناء وبعد الوفاة من أهم مهام خبراء الطب الثرعي لتحديد فترة ما بعد الوفاة. تهدف هذه الدراسة إلى التمييز بين كسور العظام الطويلة قبل و اثناء وبعد الوفاة عن طريق فحص الأنسجة الدقيق. تم تقسيم 60 فأرا إلى 6 مجموعات منساوية. اشتملت الجموعات الأولى والثانية والثالثة والرابعة على الفئران التي تعرضت لكسر في الفخذ الأيسر وتركت على قيد الحياة لمدة 6 و3 أيام و 1 يوم و12 ساعة قبل الكسر على التو الي. وشملت الهجمو عتان الخامسة والسادة على الفئران التي تم كسر الفخذ الأيسر فقط قبل الموت مبانشرة وساعتين بعد الوفاة على التو الي. تم فحص كسر العظام بعد 3 و6 أيام بعد الوفاة. كانت عينات العظم مصبوغة بصبغة الهيماتوكسلين وصبغة الترايكروم و الصبغة الزرقاء. تم تقييم النزيف، و عدد نوايا الخلايا العظمية، وعدد نو ايا نخاع العظام، ودرجة جفاف نخاع العظام. وكثفت نتائجنا أن النزف كان أكثر وضوحا في الكسر لمدة يوم واحد، ثم 3 أيام و12 ساعة، في حين أقل في 6 أيام وفي وقت الوفاة. وكان غائبا في الكسر بعد الوفاة. كان هناك انخفاض كبير في عدد الخلايا العظمية ونوى نخاع العظم، جفاف نخاع العظام، والصبغة الزرقاء عند فحصها بعد 6 أيام من الوفاة بالمقارنة مع 3 أيام بعد الوفاة. خلصت هذه الدر اسة إلى أن الهيماتوكسلين وصبغة الترايكروم قد نجحا في تقدير عمر كسر العظام الطويلة والتمييز بين الكسرقبل وبعد الوفاة ، في حين أظهرت الصبغة الزرقاء تغيرات غير هامة في الكسر الحادث قبل الوفاة مباثرة. 